\title{
$\mathrm{TiO}_{2}$ 나노입자 코팅에 의한 PET섬유의 초발수성에 관한 연구
}

\author{
박성민 $^{\dagger} \cdot$ 권일준 · 김지연 · 김창남 · 염정현 ${ }^{1} \cdot$ 윤남식 $^{2}$ \\ 한국염색기술연구소, ${ }^{1}$ 경북대학교 천연염색학과, ${ }^{2}$ 경북대학교 섬유시스템공학과
}

\section{A Study on the Super-hydrophobicity of Poly(ethylene terephthalate) Fabric by $\mathrm{TiO}_{2}$ Nano-particles Coating}

\author{
Sung-Min Park ${ }^{\dagger}$, Il-Jun Kwon, Ji-Yeon Kim, Chang-Nam Kim, \\ Jeong-Hyun Yeum ${ }^{1}$ and Nam-Sik Yoon ${ }^{2}$ \\ Korea Dyeing Technology Center, Daegu, S. Korea \\ ${ }^{I}$ Dept. of Natural Fiber Science, Kyungpook national university, Daegu, S. Korea \\ ${ }^{2}$ Dept. of Textile System Engineering, Kyungpook national university, Daegu, Korea
}

(Received: August 1, 2008/Revised: August 14, 2008/Accepted: February 9, 2009)

\begin{abstract}
Studies on plants such as lotus leaf suggested that dual-scale structure could contribute to super-hydrophobicity. We introduced super-hydrophobicity onto poly(ethylene terephthalate)(PET) fabric with dual-scale structure by assembling $\mathrm{TiO}_{2}$ nano sol. PET fabric was treated with $\mathrm{TiO}_{2}$ sol, water-repellent agent using various parameters such as particle size, concentration. Morphological changes by particle size were observed using field emmission scanning electron microscopy(FE-SEM) and AFM measurement, contact angle measurement equipment. The contact angle of water was about $138.5^{\circ}, 125.8^{\circ}, 125.5^{\circ}$ and $108.9^{\circ}$ for PET fabric coated with $60.2 \mathrm{~nm}, 120.1 \mathrm{~nm}, 200 \mathrm{~nm}$ and $410.5 \mathrm{~nm} \mathrm{TiO}_{2}$ particles, compared with about $111.5^{\circ}$ for PET fabric coated with water repellent. When we mixed particle sizes of $60.2 \mathrm{~nm}$ and $120.1 \mathrm{~nm}$ by $7: 3$ volume ratio, the contact angle of water was about $132.5^{\circ}$. And we mixed particle sizes of $60.2 \mathrm{~nm}$ and $200 \mathrm{~nm}$ by $7: 3$ volume ratio, the contact angle of water was about $141.8^{\circ}$. Also we mixed particle sizes of $60.2 \mathrm{~nm}$ and $410.5 \mathrm{~nm}$ by $7: 3$ volume ratio, the best super-hydrophobicity was obtained. In this paper, we fabricated various surface structures to the water-repellent surfaces by using four types of $\mathrm{TiO}_{2}$ nano-particles, and we found that the nanoscale structure was very important for the super-hydrophobicity.
\end{abstract}

Keywords: sol-gel, super-hydrophobic, water repellent, lotus effect, contact angle

\section{1. 서 론}

나노기술은 직경 $1 \sim 100 \mathrm{~nm}$ 크기의 원자나 분자 를 조작/제어하여 물질의 구조와 배열을 변화시켜, 새로운 기능이나 우수한 특성을 만들어내는 기술 이다 ${ }^{1,2)}$. 입자가 나노화되면 비표면적이 상당히 넓 어져서 나노재료의 접착력이 크게 강화되고, 내구 성이 증가되며, 동시에 특별한 기능성이 나타난다.

섬유산업에 있어서 나노기술이 적용되거나 응 용이 검토되는 분야는 스포츠 의류, 특수복, 군사 용, 보호복, 산업용, 스마트섬유 등에 이르기까지 그 폭이 넓은데, 국내에서는 자체적으로 개발하여 상품화된 사례가 거의 없다.
섬유산업에 대한 나노기술의 적용은 고부가가 치 섬유 신제품 제조가 가능하고, 부가가치가 높 아 우리나라 섬유산업의 부흥을 이끌 수 있는 주 요 상품화기술이라 생각된다.

최근 들어 나노 크기를 관찰할 수 있는 측정기 술의 발달과 더불어 자연계에서 관찰되는 발수구 조와 비슷한 메카니즘을 사용하여 초발수성을 얻 으려는 시도가 증가하고 있다. 그 중에서도 나노 돌기를 가지고 있는 로투스 효과(lotus effect)의 구현이 큰 관심을 끌고 있다. 로투스 효과를 가지 는 표면의 소수성을 결정하는 요소는 표면거칠기 와 표면에너지인데, 이 두 가지 조건을 변화시킴 으로써 소수성 정도를 조절할 수 있으며, 초소수

${ }^{\dagger}$ Corresponding author. Tel.: +82-53-350-3770; Fax.: +82-53-350-3737; e-mail: psungmin@empal.com 
성 표면을 구현할 수 있다 ${ }^{3-9)}$. 이러한 연구는 독일 의 화학회사 BASF에서 연잎이 물방울과 먼지 입 자들에 반발하는 원리를 이용하여 스프레이 코팅 제를 개발하고 있으며 이 가공제는 폴리프로필렌, 폴리에틸렌, 왁스와 같은 소수성 고분자들을 나 노입자들과 결합시켜 이를 종이나 가죽, 석조 구 조물 등과 같은 표면에 분사 후 표면이 마르면서 나노구조 코팅막을 형성시켜 초소수성 표면을 구 현한다. 또한 나노입자들 간의 분자들 사이에 영 향을 미치는 van der waals 상호작용에 의해 나노 입자들이 서로 들러붙고 구부러지고 침강하여 마 이크로 입자위에 나노입자가 존재하는 듀얼스케일 구조가 생성되며 이러한 구조는 연잎의 미세구조 물과 유사한 특성을 보여 발수성을 나타낸다 ${ }^{10)}$.

현재 초소수성 표면을 구현하고자 여러 화학업 체에서 초발수제를 개발하여 섬유에 적용하고 있 으나, 섬유에 처리 시 내구성이 떨어지거나 초소수 성 구현에 한계를 가지고 있다. 초소수성 표면을 구현하기 위한 연구로는 연잎의 표면과 같은 양상 의 표면거칠기를 증가시키는 연구가 진행되고 있 으며, 이를 위한 방법으로는 플라즈마 삭각, 나노 자기조립, 졸겔 나노입자 합성 및 부착 등의 방법 이 있으며, 그 중 플라즈마 삭각 방법은 처리의 균 일성 및 재현성이 불량 및 처리된 섬유의 강도가 저하되는 문제가 있으며, 처리매질의 표면에서 나 노입자의 자기조립방법은 섬유공정상 적용이 어려 운 점이 있어, 본 논문에서는 졸겔법을 이용한 초 소수성 표면을 구현하고자 한다. 졸겔법으로 제조 된 콜로이드 용액은 섬유가공에 적용하기 쉬우며, 섬유고분자와 직접 결합하여 실용성을 지닌다 ${ }^{11)}$.

본 논문에서는 졸겔법을 이용해 여러 크기의 $\mathrm{TiO}_{2}$ 나노 입자를 제조하여 이를 PET 섬유에 처 리하여 듀얼스케일의 표면 돌기를 생성토록 하였 다. 이를 통하여 만들어진 극소수성 표면은 여러 크기의 나노입자가 동시에 존재하는 코팅물로써 자연계에 존재하는 극소수성 표면인 연잎과 유사 한 구조물을 형성하게 된다. 입자 크기에 따라 접 촉각의 변화가 생길 것으로 생각되며 이러한 차 이를 본 논문에서 규명하고자 한다.

\section{2. 실 험}

\section{$2.1 \mathrm{TiO}_{2}$ 졸 제조 및 장치}

$\mathrm{TiO}_{2}$ 졸 제조는 Fig. 1과 같이 전구체로 TTIP [Titanum $(\mathrm{IV})$ isopropoxide, $98.0 \%$ Junsei], 용매로 초순수와 에탄올 $\left[\mathrm{C}_{2} \mathrm{H}_{5} \mathrm{CH}, 95.8 \%\right.$, Duksan], 촉매로 질산 $\left[\mathrm{HNO}_{3}, 62.0 \%\right.$, Yakuri]을 사용하였다. 또한 $\mathrm{TiO}_{2}$ 졸의 입자 크기를 조절하기 위해 TTIP의 몰 비를 조절하여 입자를 제조하였다.

\section{$2.2 \mathrm{TiO}_{2}$ 졸/발수제 코팅}

Table 1 의 조건으로 제조된 $\mathrm{TiO}_{2}$ 졸을 부피비로 $\mathrm{KS} \mathrm{K} 0905$ 규격의 폴리에스테르 표준백포에 1 차로 $170^{\circ} \mathrm{C}$ 에서 1 분간 큐어링 처리하였다. 2 차로 $1000 \mathrm{~m} \ell$ 메스플라스크 안에 발수제 $5 \mathrm{~g}$ 을 넣고 표시 선까지 증류수를 채워서 o.w.s. $0.5 \%$ 불소고분자의 탄소수가 6개인 플르오르 실란계 발수제(Unidyne TG-5521, Daikin)를 사용하여, $180^{\circ} \mathrm{C}$ 에서 1 분간 큐 어링하여 처리하였다. 여기서 o.w.s.란 부피용액속에 투입된 조제의 무게비를 의미하며 단위로는 $\mathrm{g} / \ell$ 를 사용한다. 또한 입자 크기가 다른 $\mathrm{TiO}_{2}$ 졸을 혼합 하여 위와 같은 조건으로 1 차 코팅한 후 발수제를 2 차로 처리하여 그에 따른 물성을 평가하였다.

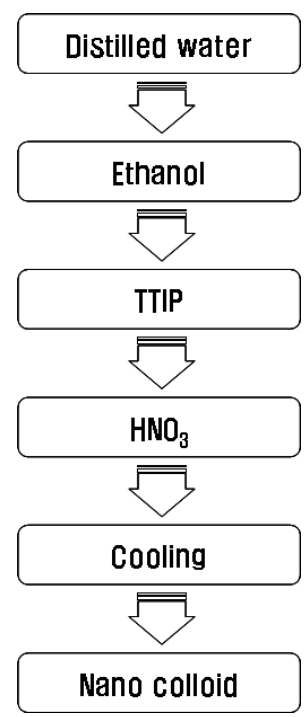

Fig. 1. Preparation scheme for $\mathrm{TiO}_{2}$ nano sol by TTIP.

Table 1. $\mathrm{TiO}_{2}$ sol and Water repellency coating conditions

\begin{tabular}{ccc}
\hline & $\mathrm{TiO}_{2}$ sol coating & Water repellency coating \\
\hline Pick-up ratio(\%) & $68 \%$ & $68 \%$ \\
Curing conditions & $170{ }^{\circ} \mathrm{C} \times 60 \mathrm{sec}$ & $180^{\circ} \mathrm{C} \times 60 \mathrm{sec}$ \\
Concentration of auxiliary & oligomer $2.5 \%(20 \mathrm{~g} / 1 \sim 40 \mathrm{~g} / \mathrm{l})$ & $1 \mathrm{~g} / 1 \sim 10 \mathrm{~g} / \mathrm{l}$ \\
\hline
\end{tabular}




\subsection{XRD 측정}

제조된 입자의 결정성을 알아보기 위해 XRD (X-ray diffraction, $\mathrm{D} / \max 2500$, Rigaku)의 회절분석 에 사용된 $\mathrm{X}$ 선 파장은 $\mathrm{Cu}-\mathrm{K} \alpha 1(\lambda=1.540598 \AA)$ 을 사용하였으며, 스캔 속도 $8^{\circ} / \mathrm{min}, 2 \theta$ 는 $10^{\circ} \sim 80^{\circ}$, 출력전압과 전류는 각각 $40 \mathrm{kV}, 20 \mathrm{~mA}$ 이었다.

\section{4 입도 측정}

제조된 입자의 균일한 입자분포와 크기를 알아 보기 위해 입도분포분석기(ELS-8000, OTSUKA) 로 분석하였으며, 측정횟수는 50 회이다.

\section{5 발수도 측정}

$\mathrm{TiO}_{2}$ 졸의 입자크기에 따른 발수성을 알아보기 위해 먼저 발수제만 폴리에스테르 직물에 패딩하 여 발수성이 떨어지는 시점을 알아보기 위해 발수 도 측정을 하였다. 발수도 측정은 AATCC 22 방 법으로 $250 \mathrm{~mL}$ 의 증류수를 25 초간 분무하여 평가 하였으며, 규격에 따라 발수도 평가는 100,90 , $80,70,50,0$ 으로 표기하였다.

\section{6 접촉각 측정}

$\mathrm{TiO}_{2}$ 졸과 발수제 처리된 폴리에스테르 직물의 표면성상 및 물리적 특성변화는 표면자유에너지 변화, 즉, 표면장력의 변화를 확인할 수 있는 접 촉각을 측정함으로서 확인이 가능하여 접촉각측 정기(DSA100, Kruss, Germany)를 사용하여 측정 하였다. 각 측정에서 용액은 $10 \mu$ 의 양만큼 떨어 뜨린 후 측정하였으며, 3 회 반복 측정하여 평균값 과 편차를 구하였다. 이 때 증류수를 사용하였으 며, 디지털 카메라를 이용하여 사진으로 촬영해 소수성을 평가하였다.

Fig. 2는 입자 크기에 따른 접촉각을 알아보기 위한 모식도이다.

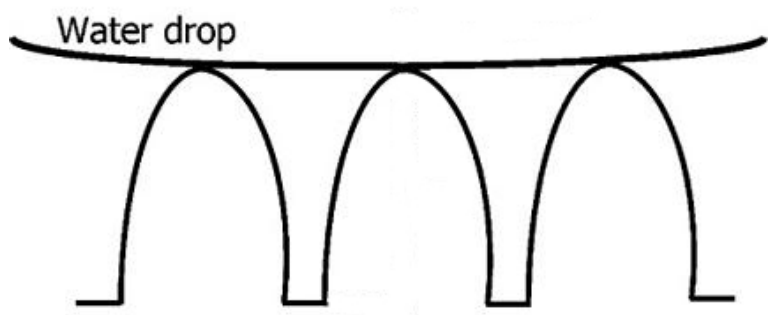

Coated surface

Fig. 2. Diagram of water drop on PET surface.

\section{7 표면상태 측정}

$\mathrm{TiO}_{2}$ 졸과 발수제 처리된 폴리에스테르 직물의 표면 상태를 측정은 표면 미세구조 변화를 나노 레벨까지 관찰가능 한 전계방사형 주사전자현미 경(FE-SEM, JSM-7500A, JEOL)을 사용하였으며, 가속전압 $1 \mathrm{kV}$, 전류 $9 \mathrm{~mA}$ 로 측정하였다. 또한 원 자력간현미경(AFM, Digital instruments, NanoScope Multimode)으로 표면 형상을 알아보았다.

\section{3. 결과 및 고찰}

\section{1 $\mathrm{TiO}_{2}$ 의 결정성 확인 및 TTIP 몰비에 따른 입자크기 측정}

Fig. 3은 제조한 입자의 결정성을 알아보기 위 해 X-ray 측정한 결과 $2 \theta=25.3^{\circ}$ 에서 결정형을 띠는 것을 확인했다. 그러나 TTIP $1.173 \mathrm{M}$ 이상을 투입하여 $\mathrm{TiO}_{2}$ 졸을 제조할 경우 피크의 강도가 감소하는 것을 확인하였다. 강도가 감소하는 것은 무결정상을 나타내는 것을 의미하며, 제조된 용액 을 확인한 결과 콜로이드 상태를 유지하지 않고 입자가 가라앉은 것을 확인할 수 있었다.

Fig. 4는 TTIP 몰비에 따른 $\mathrm{TiO}_{2}$ 졸을 제조하 여 입도 측정한 결과 비교적 균일한 입자 분포를 가지며 입자 크기는 몰비 $0.32 \mathrm{M}, 0.704 \mathrm{M}, 0.102 \mathrm{M}$, $1.173 \mathrm{M}$ 일 때 각각 $60.2 \mathrm{~nm}, 120.1 \mathrm{~nm}, 200 \mathrm{~nm}, 410.5 \mathrm{~nm}$ 의 입자를 얻을 수 있었다. 나노졸 제조는 전구체 (TTIP)의 농도 뿐 아니라 교반속도, 촉매, 온도 등 의 조건에 따라 나노입자의 크기가 달라지는데, 본 논문에서는 전구체인 TTIP의 몰비 변화로 다양한 입자 크기의 $\mathrm{TiO}_{2}$ 졸을 제조하였다. TTIP의 몰비 가 커지면 입자의 크기가 커지며, 그와 반대로 TTIP의 몰비가 작아지면 입자의 크기는 작아진다.

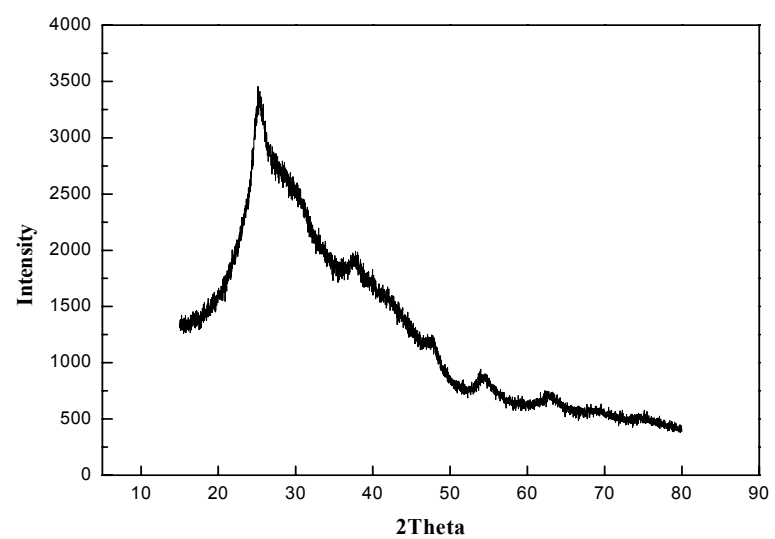

Fig. 3. X-ray diffraction pattern of $\mathrm{TiO}_{2}$ nano sol. 


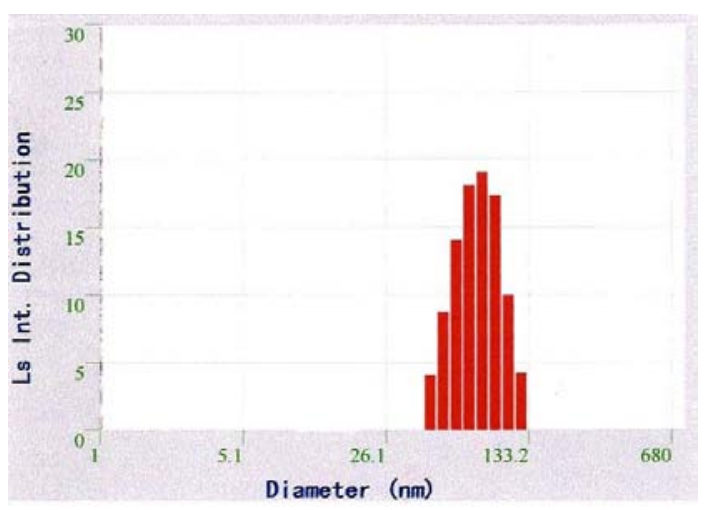

(a) $60.2 \mathrm{~nm}$

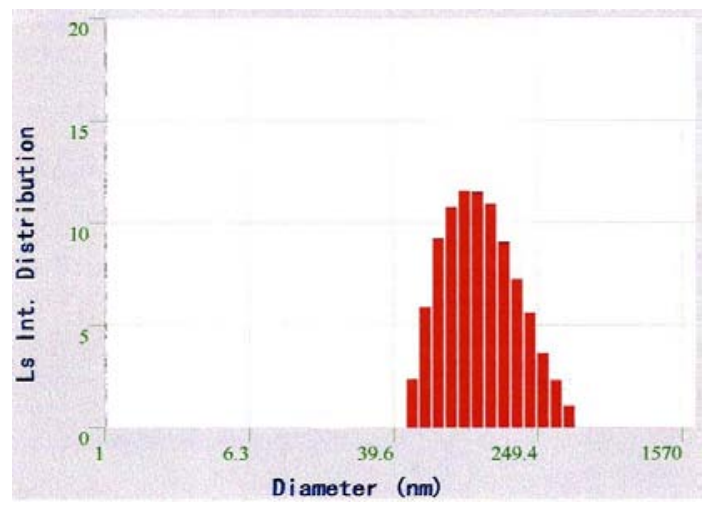

(c) $200 \mathrm{~nm}$

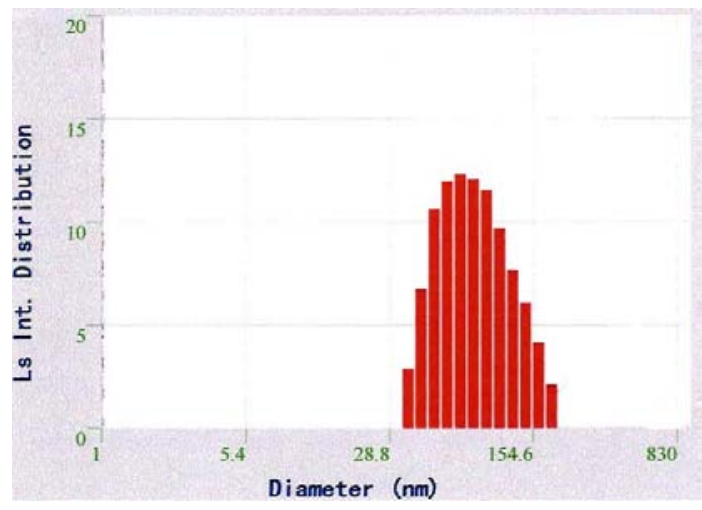

(b) $120.1 \mathrm{~nm}$

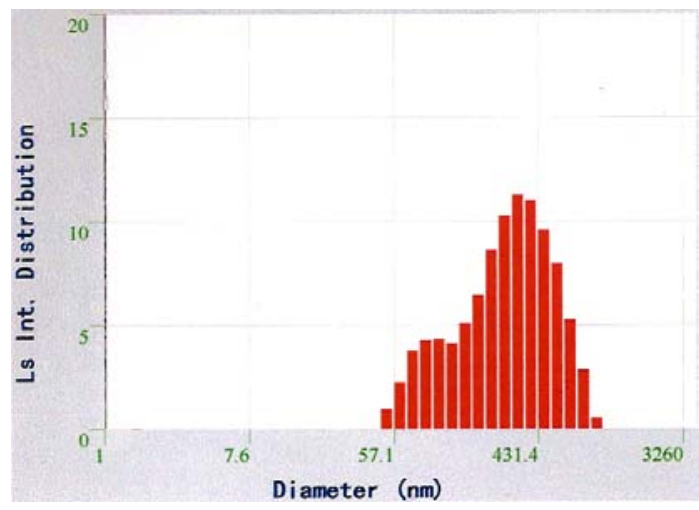

(d) $410.5 \mathrm{~nm}$

Fig. 4. Particle size of $\mathrm{TiO}_{2}$ nano sol according to TTIP mol ratio.

그러나 TTIP의 몰비가 너무 높거나 작게 되면 물과의 가수분해나 축합 반응이 제대로 이루어지 지 못해 응집이 일어나므로 적당한 전구체의 몰 비를 유지해 주어야 한다.

\section{$3.2 \mathrm{TiO}_{2} /$ 발수제 처리에 따른 발수도 및 접촉각 측정}

Fig. 5는 $\mathrm{TiO}_{2}$ 졸의 입자크기에 따른 발수성을 알아보기 위해 먼저 발수제만 폴리에스테르 직물 에 패딩하여 발수성이 떨어지는 시점을 알아보기 위해 발수도 측정을 한 결과이다. o.w.s. 0.8 0.6\% 발수제를 처리하였을 경우 발수도는 100 이 나왔으 며 발수제 처리 o.w.s. $0.5 \%$ 부터 발수도가 떨어지 기 시작했다. $\mathrm{TiO}_{2}$ 졸의 입자 크기에 따른 발수도 를 알아보기 위해 본 논문에서는 발수제 처리 o.w.s. $0.5 \%$ 를 고정하여 2차 패딩하였다. 1 차, 2 차 패딩에 앞서 발수제에 나노입자를 혼입했을 경우 나노입자의 친수성이기 때문에 발수도를 저하시키 는 문제가 발생하였다. 따라서 본 연구에서는 나노 입자를 이용해서 나노돌기를 형성시키고 그 나노 돌기 위에 불소고분자를 코팅하여 표면접촉각 개
선효과를 확인하고자 하였다.

Fig. 6은 발수제 특성을 좀 더 자세히 알기 위해 접촉각을 평균 측정한 결과이다. O.w.s. $0.8 \%$ 의 발 수제를 처리하였을 경우 접촉각은 $129^{\circ}$ 가 나왔으 며, 발수제 양을 줄여감에 따라 접촉각이 작아짐을 알 수 있었다.

Fig. 7은 4종의 입자 크기별로 폴리에스테르 직 물에 고형분 $2.5 \% \quad \mathrm{TiO}_{2}$ 졸에 o.w.s. $2 \%, 4 \%$ 1차 패딩한 후 o.w.s. $0.5 \%$ 의 발수제를 패딩한 후 그 에 따른 접촉각 측정 결과이다. $60.2 \mathrm{~nm}, 120.1 \mathrm{~nm}$, $200 \mathrm{~nm}, 410.5 \mathrm{~nm}$ 의 접촉각은 0.w.s. $2 \%$ 일 때 각각 $138.5^{\circ}, 130.0^{\circ}, 129.7^{\circ}, 109.8^{\circ}$ 이고 o.w.s. $4 \%$ 일 때 접촉각은 $130.1^{\circ}, 125.8^{\circ}, 125.5^{\circ}, 108.9^{\circ}$ 이며, 이는 평균 측정값이며 오차는 $3^{\circ}$ 이다. 이는 o.w.s. $0.8 \%$ 발수제만을 처리할 때보다 $60.2 \mathrm{~nm}$ 의 $\mathrm{TiO}_{2}$ 졸을 처리한 후 발수제를 처리한 경우가 접촉각이 $10^{\circ}$ 정도 높았다. 또한 o.w.s. $0.3 \%$ 발수제 단독 처리 한 경우와 $410.5 \mathrm{~nm}$ 의 $\mathrm{TiO}_{2}$ 졸을 처리한 경우의 접촉각은 $109.8^{\circ}$ 로 별다른 차이를 보이지 않았다. 이처럼 물방울과 나노돌기와의 접촉면적이 커지 면 접촉각이 줄어들어 결과적으로 친수성을 증가 


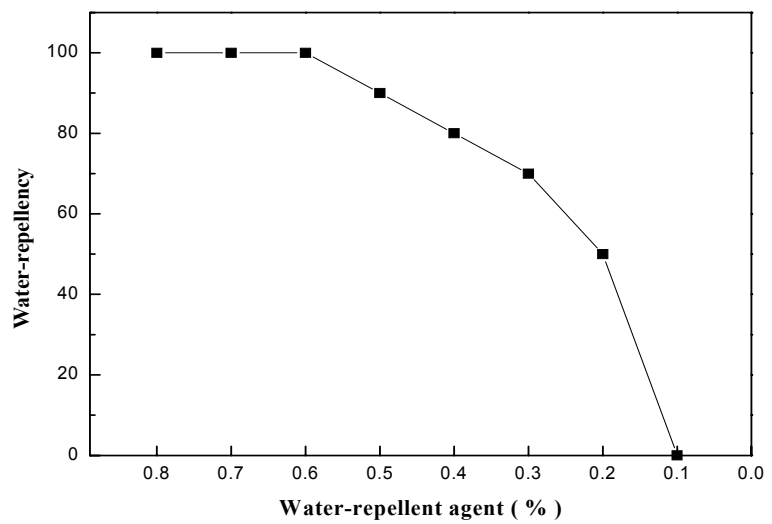

Fig. 5. Water repellency according to water repellent agent(\%).

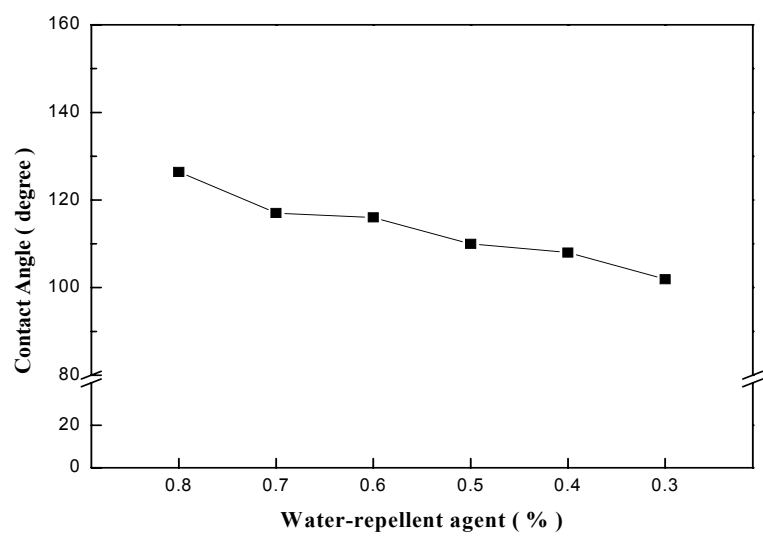

Fig. 6. Contact angle according to water repellent agent(\%).

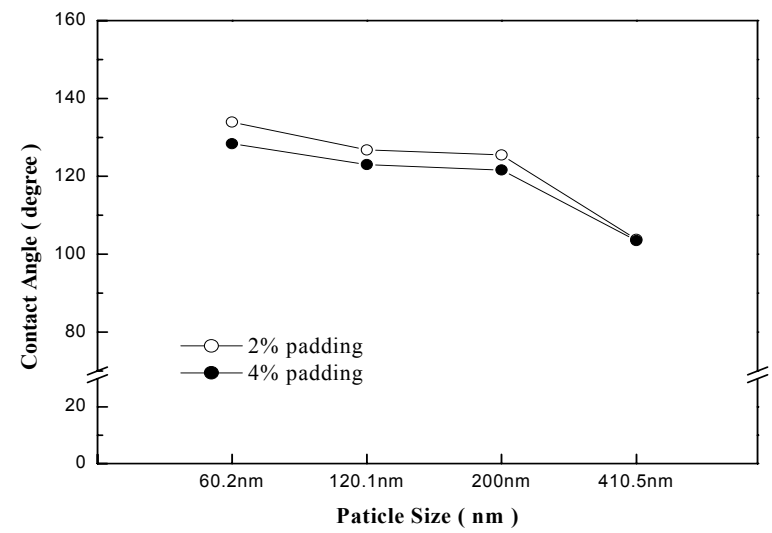

Fig. 7. The relationship between contact angle and particle size.

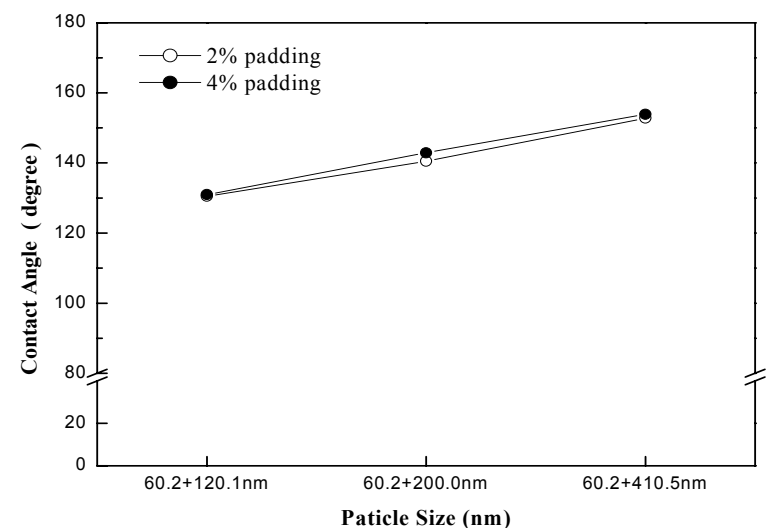

Fig. 8. The relationship between contact angle and mixed particle size.

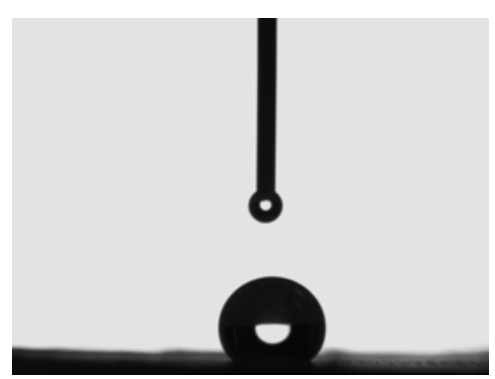

(a) $60 \mathrm{~nm}+120 \mathrm{~nm} 2 \%$

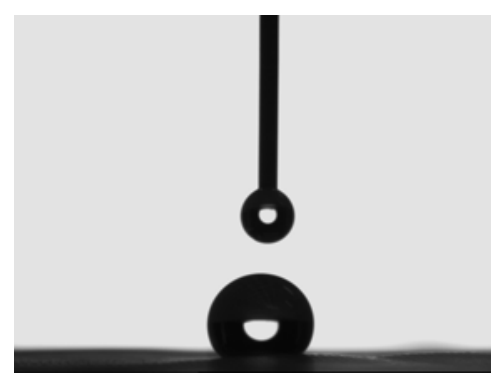

(d) $60 \mathrm{~nm}+200 \mathrm{~nm} 4 \%$

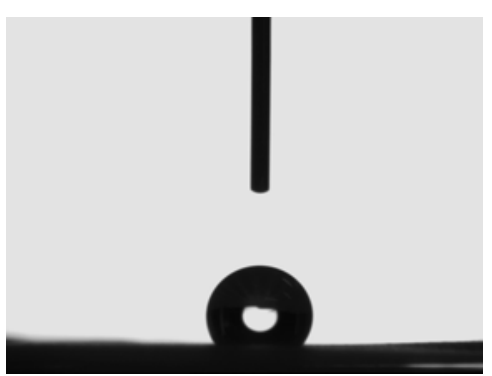

(b) $60 \mathrm{~nm}+120 \mathrm{~nm} 4 \%$

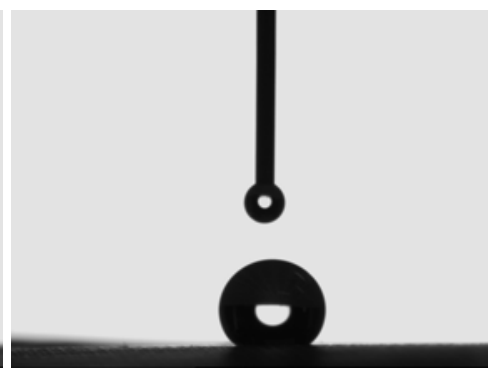

(e) $60 \mathrm{~nm}+400 \mathrm{~nm} 2 \%$

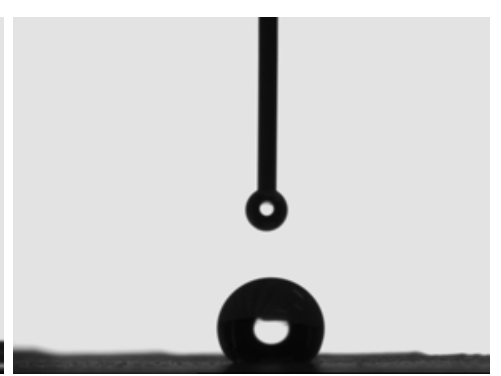

(c) $60 \mathrm{~nm}+200 \mathrm{~nm} 2 \%$

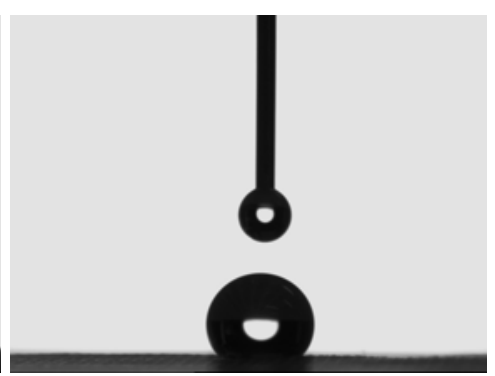

(f) $60 \mathrm{~nm}+400 \mathrm{~nm} 4 \%$

Fig. 9. Contact angle according to mixed particle size: o.w.s $2 \%$ and $4 \%$ treated. 
시킴을 알 수 있다.

Fig. 8과 Fig. 9는 자연계에 존재하는 연잎의 미세 구조와 같은 원리를 이용해 듀얼스케일의 나노돌기를 만들어 그에 따른 접촉각을 측정한 결과이다. 세부조건으로서 $\mathrm{TiO}_{2}$ 졸 입자 중 가장 작은 $60.2 \mathrm{~nm}$ 크기의 입자와 $120.1 \mathrm{~nm}, 200.0 \mathrm{~nm}$, $410.5 \mathrm{~nm}$ 의 입자를 $5: 5$ 비율로 혼합한 후 o.w.s. $2 \%$, o.w.s. $4 \% \mathrm{TiO}_{2}$ 졸을 1차 패딩 후 2차로 같 은 조건으로 발수제를 처리하였다.

o.w.s. $2 \%$, o.w.s. $4 \% \mathrm{TiO}_{2}$ 졸을 처리한 폴리에 스테르 직물의 접촉각을 측정한 결과 $\pm 3^{\circ}$ 오차범 위 안에서 비슷하게 나왔으며, $60.2 \mathrm{~nm} / 120.1 \mathrm{~nm}$ 혼합한 경우 접촉각은 $132.5^{\circ}, 60.2 \mathrm{~nm} / 200.0 \mathrm{~nm}$ 의 경우 $141.8^{\circ}, 60.2 \mathrm{~nm} / 410.5 \mathrm{~nm}$ 의 경우 $155.4^{\circ}$ 로 극 소수성을 나타내었다. 이는 물방울과 섬유 표면의 접촉면적이 가장 작은 것을 나타내며, 나노스케일 의 구조를 동시에 갖는 듀얼스케일 구조물이 소 수성을 증가시킴을 알 수 있다.
Fig. 10은 Fig. 8의 결과에서 가장 접촉각이 크 게 나온 $60.2 \mathrm{~nm}$ 의 입자와 $410.5 \mathrm{~nm}$ 의 입자를 $5: 5$ 비율로 혼합하였을 때 극소수성기를 나타낸 결과 를 토대로 9:1 1:9비율로 듀얼스케일의 입자를 혼 합한 후 그에 따른 접촉각을 알아본 결과이다.

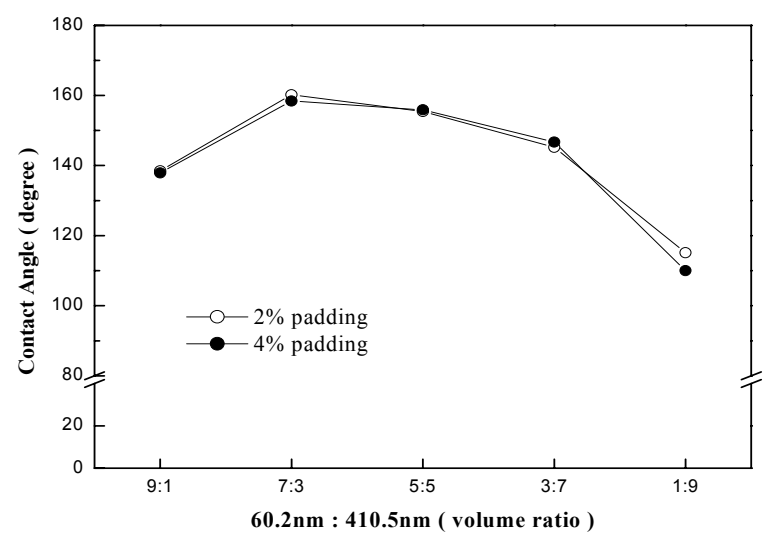

Fig. 10. The relationship between contact angle and mixed particle size according to volume ratio.

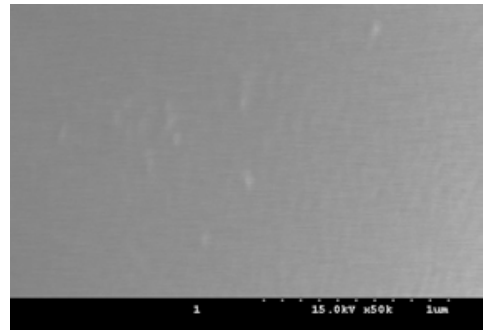

(a) repellent agent treated $(\times 50,000)$

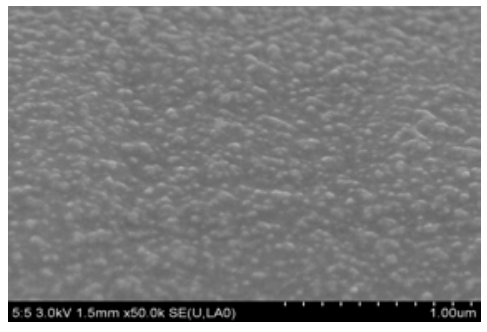

(d) $5: 5(\times 50,000)$

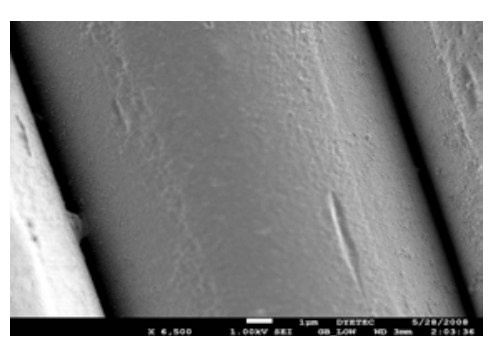

(g) $7: 3(\times 6,500)$

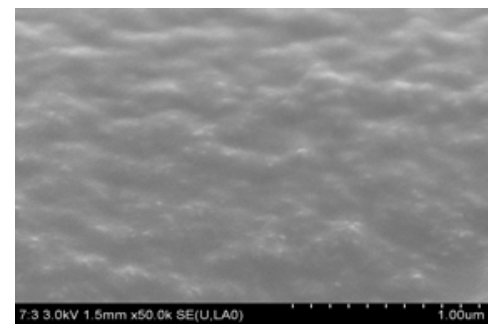

(b) $1: 9(\times 50,000)$

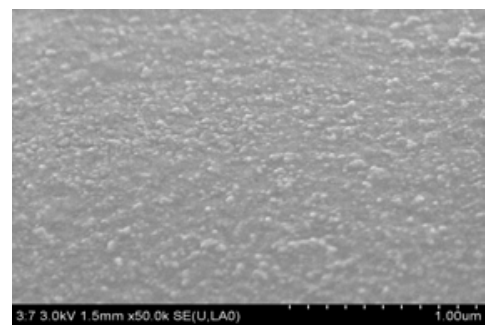

(e) $7: 3(\times 50,000)$

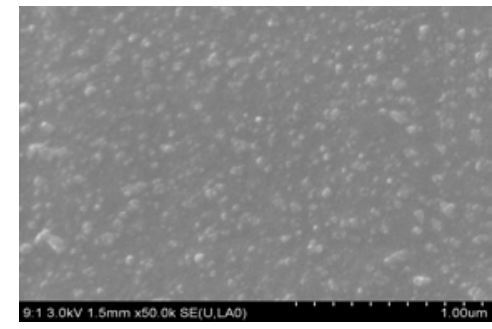

(c) $3: 7(\times 50,000)$

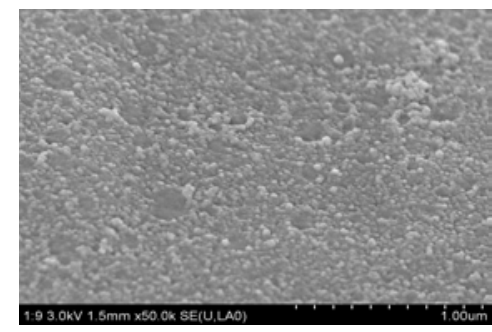

(f) $1: 9(\times 50,000)$

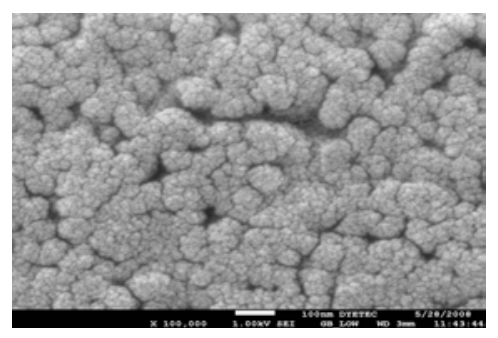

(h) $7: 3(\times 100,000)$

Fig. 11. FE-SEM images of PET fabrics: treatment of $60.2 \mathrm{~nm} / 410.5 \mathrm{~nm}$ particle size according to volume ratio. 


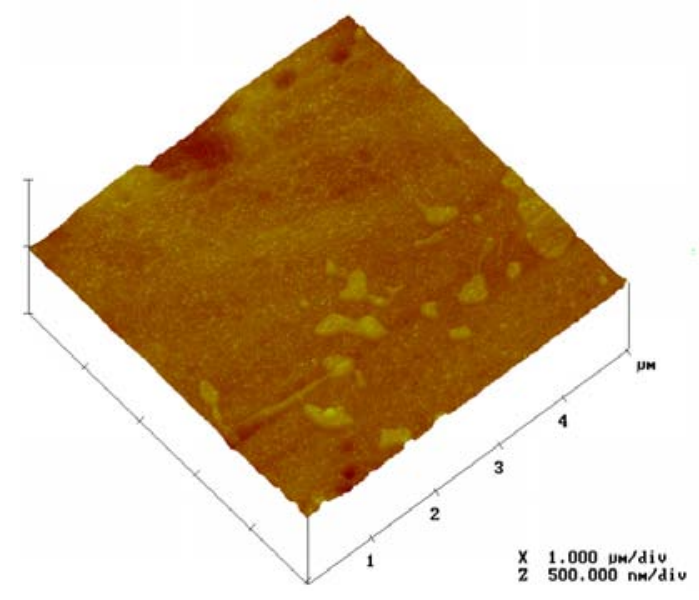

(a) untreated

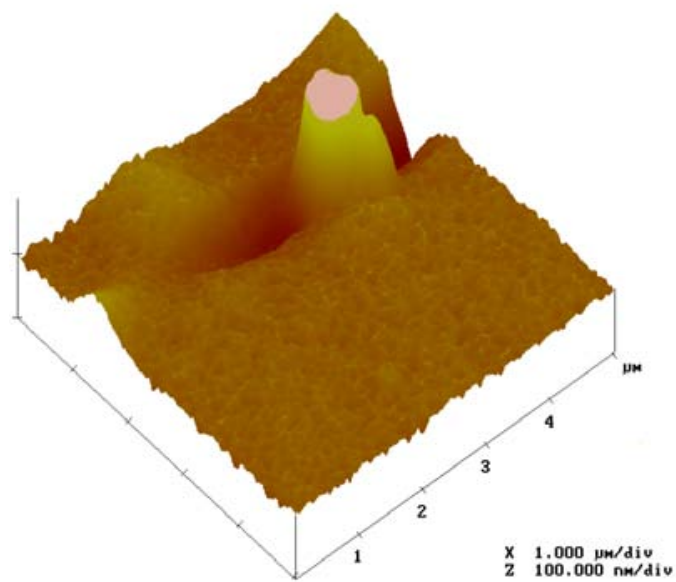

(b) water repellent treated

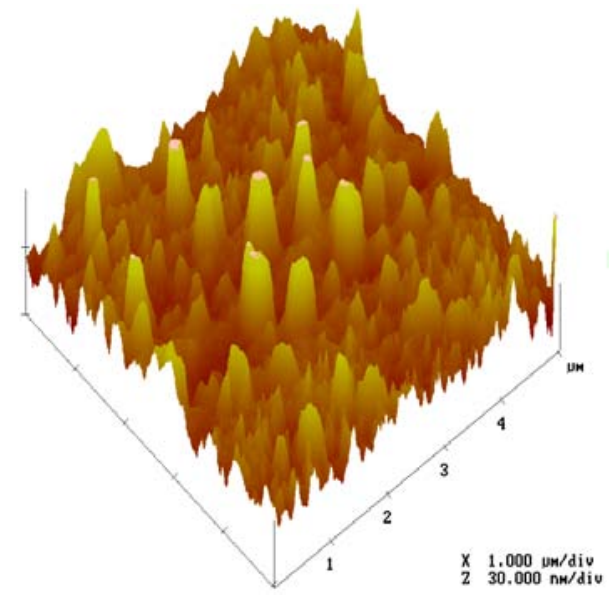

(c) $\mathrm{TiO}_{2} /$ water repellent treated

Fig. 12. AFM images of PET fabrics.

$60.2 \mathrm{~nm}$ 의 입자와 $410.5 \mathrm{~nm}$ 의 입자의 비율 $7: 3$ 일 때 접촉각이 $161.5^{\circ}$ 로 가장 크게 나타났으며, 1:9 의 비율로 혼합한 경우 $112^{\circ}$ 로 가장 작게 나왔다. 이는 물방울과 섬유표면의 접촉면적이 가장 커 소수성기가 낮아진 것으로 생각된다.

서로 다른 크기의 나노입자로 이루어진 듀얼스 케일의 나노구조물 위에 물방울을 떨어뜨리면, 물 방울은 듀얼스케일의 나노구조물 꼭지점과 접촉 하게 되고, 꼭지점 아래의 구조물로는 물방울이 침투할 수 없게 된다. 즉 물방울과 고체표면과의 접촉면적이 극소로 감소하게 되고, 이는 극소수성 으로 나타나게 된다.

\section{3 $\mathrm{TiO}_{2} /$ 발수제 코팅에 따른 표면 변화}

Fig. 11은 가장 접촉각이 크게 나온 $60.2 \mathrm{~nm}$ 의 입자와 $410.5 \mathrm{~nm}$ 의 입자를 9:1 1:9비율로 듀얼스 케일의 입자를 혼합한 후 전계방사형 주사현미경
50,000 배 배율로 관찰한 사진이다. (a)는 $\mathrm{TiO}_{2}$ 졸 을 처리하지 않고 발수제만 처리하여 찍은 사진 이며 일반발수제 처리 양상과 비슷한 형상을 띠 었다. (b)는 $410.5 \mathrm{~nm}$ 의 입자 비율이 많이 들어가 사진과 같이 나노돌기가 매우 큰 것을 확인할 수 있었으며, $60.2 \mathrm{~nm}$ 입자의 비율을 높여감에 따라 연잎 모양의 듀얼스케일 형상을 띠는 것을 확인하였다. $(\mathrm{g})$ 는 6,500 배의 배율로 관찰한 사진 으로 섬유 표면상에 $\mathrm{TiO}_{2}$ 나노돌기가 균일하게 부착되어 있는 현상을 확인할 수 있었으며 (h)는 100,000 배의 배율로 관찰한 사진으로 라즈베리 (raspberry) 구조의 형상을 관찰할 수 있었다.

Fig. 12는 표면 형상을 알아보기 위해 AFM을 찍은 결과이다. (a)는 미처리 폴리에스테르 섬유, (b)는 o.w.s. $0.5 \%$ 발수제 처리한 섬유로 발수제에 의해 표면에 작은 요철이 생긴 것을 확인할 수 있 었다. (c)는 $\mathrm{TiO}_{2}$ 졸을 1 차 패딩한 후 2 차로 발수 
제 처리한 섬유로서 FE-SEM에서 확인한 나노돌기 를 볼 수 있었다.

\section{4. 결 론}

본 논문에서는 연잎을 모방한 로투스 효과를 구 현하고자 폴리에스테르 직물에 $\mathrm{TiO}_{2}$ 나노입자를 크기별로 제조하여 그에 따른 접촉각 변화를 비 교 분석하고 표면 관찰하여 아래와 같은 결과를 얻었다.

1. 입자가 $60.2 \mathrm{~nm}$ 일 때 접촉각은 $138.5^{\circ}$ 이며 입자 가 커질수록 접촉각은 작아졌지만 발수제 단독 으로 처리한 경우에 비하여 더 큰 접촉각을 얻 었다.

2. 입자 $60.2 \mathrm{~nm}$ 와 $120.1 \mathrm{~nm}, 200.0 \mathrm{~nm}, 410.5 \mathrm{~nm}$ 의 입자를 5:5 비율로 혼합한 후 접촉각을 측정한 결과 $60.2 \mathrm{~nm} / 410.5 \mathrm{~nm}$ 의 경우 $155.4^{\circ}$ 로 초발수 성능을 나타내었다.

3. $60.2 \mathrm{~nm}$ 의 입자와 $410.5 \mathrm{~nm}$ 의 입자를 $7: 3$ 의 비 율로 혼합하였을 때 가장 큰 접촉각을 얻었다.

\section{참고문헌}

1. T. Young, Philosophical Transaction of the Royal Society of London, pp.65-87, 1805.

2. W. Barthlott, C. Neinhuis, Purity of the Sacred Lotus, or Escape from Contamination in Biological Surfaces, Planta, 202(1), 1-8(1997).

3. Y.L. Linda, Wu, A.M. Soutar, X.T. Zeng, Increasing Hydrophobicity of Sol-gel Hard Coating by Chemical and Morphological Modification, Surface \& Coating Technology, 198 (1/3), 420-424(2005).
4. H. Schmidt, G. Jonschker, S. Goedicke and M. Nennig, The Sol-Gel Process as a Basic Technology for Nanoparticle-Dispersed InorganicOrganic Composites, J. Sol-Gel Sci. Technol., 19, 39-51(2000).

5. L. F. Francis, Sol-Gel Methods for Oxide Coatings, Intermetallic and Ceramic Coatings, M. Dekker, New York, pp.31-82, 1999.

6. C. Schramm, W. H. Binder and R. Tessadri, Durable Press Finishing of Cotton Fabric with 1,2,3,4-Butanetetracarboxylic Acid and TEOS/ GPTMS, J. Sol-Gel Sci. Technol., 29, 155-165(2004).

7. C. J. Brinker and G. W. Scherer, "Sol-Gel Science", ed. C.J.Brinker, Academic Press, San Diego, p.22, 1990.

8. B. Mahltig, D. Knittel, E. Schollmeyer and H. Bottcher, Incorporation of Triarylmethane Dyes into Sol-Gel Matrices Deposited on Textiles, J. Sol-Gel Sci. Technol., 31, 293-297(2004).

9. B. Mahltig and H. Bottcher, Modified Silica Sol Coatings for Water-Repellent Textiles, $J$. Sol-Gel Sci. Technol., 27, 43-52(2003).

10. J. Jürgen, G. Holger and Y. Rachel, Wetting Behavior of Water Droplet on Hydrophobic Microtextures of Comparable Size, Langmuir, 20(23), 10015-10019(2004).

11. I. Brasack, H. Bottcher and U. Hempel, Biocompatibility of Modified Silica-Protein Composite Layers, J. Sol-Gel Sci. Technol., 19, 479-482 (2000). 